Annals of Warsaw University of Life Sciences - SGGW

Horticulture and Landscape Architecture No 40, 2019: 15-28

(Ann. Warsaw Univ. of Life Sci. - SGGW, Horticult. Landsc. Architect. 40, 2019)

DOI 10.22630/AHLA.2019.40.2

\title{
Use of structural soil as a method for increasing flood resilience in Praga Północ in Warsaw
}

\author{
MAGDALENA WOJNOWSKA-HECIAK ${ }^{1}$, MARZENA SUCHOCKA ${ }^{2}$, \\ BARBARA GRZEBULSKA ${ }^{3}$, MARTA WARMIŃSKA ${ }^{2}$ \\ ${ }^{1}$ Faculty of Civil Engineering and Architecture, Kielce University of Technology \\ ${ }^{2}$ Faculty of Civil and Environmental Engineering, Warsaw University of Life Sciences - SGGW \\ ${ }^{3}$ Regional Environmental Centre (REC)
}

\begin{abstract}
Use of structural soil as a method for increasing flood resilience in Praga Pótnoc in Warsaw. The observed climate changes result in repeated volatile rains and consequently local flooding. Urbanization and "sealing" of cities means that the sewage system becomes inefficient and cannot cope with the total rainfall. Therefore, new strategies and solutions for managing rainwater and increasing flood resilience in urban areas are in continuous need of development. The basic research question is to determine whether using structural soil placed under pedestrian and courtyard surfaces in urban areas can increase their water retention capacity. Research methods are limited to qualitative and quantitative methods. Introducing the parameters of the maximum heavy rain recorded for the western part of Warsaw (rainfall station in Bielany, volatile rainfall from $2013-38.5 \mathrm{~mm}$ of rain fell in $90 \mathrm{~min}$ ), around $6,502 \mathrm{~m}^{3}$ of rain would fall in total on the study area. Assuming that under the pavements and courtyards there is a base layer made of structural soil with a porosity of $30 \%$ on average, if we just used $100 \mathrm{~mm}$ of this layer, we would obtain over $2,218.5 \mathrm{~m}^{3}$ of water storage. In conclusion, structural soil used under pedestrian and courtyard surfaces would significantly improve rainwater retention in the study area in Praga Pólnoc in Warsaw and reduce local flooding.
\end{abstract}

Key words: structural soil, flood resilience, water retention

\section{INTRODUCTION}

McHarg in the paper "An Ecological Method for Landscape Architecture", as well as in his monograph "Design with Nature" he already wrote about how important it is to change the approach to designing urban landscapes over 40 years ago (McHarg 1967, 1969). He emphasized the role of ecology, which ought become the basis for the work of architects and landscape architects, as well as planners. He also wrote about the importance of landscape architects in shaping a new approach to design. He described this role as a kind of bridge connecting on the one hand natural science related to ecology, and on the other planning and designing, as the study of connections and dependencies between organisms and the environment (Beatley 2008).

Use of structural soil for the increase of water retention, and thus supporting city flood resilience, is an under-researched topic. Describing the use of structural soil, more often aspects of improving trees' habitat conditions exposed 
to strong anthropopressure are discussed (Grabosky and Bassuk 1996). Due to the observed climate changes, including perturbations of the rainfall during the year, the importance of landscape-based, non-invasive solutions operating in accordance with above mentioned theories of McHarg supporting rainwater retention in cities has increased (Wojnowska-Heciak and Janus 2016). Flash floods and urban droughts have become an element of urban life. According to Welle and Birkmann (2015), flash floods, among others, account for $81 \%$ of the most frequent and devastating natural hazards and $83 \%$ of connected fatalities. In recent years, flash floods have occurred more often, causing damage estimated in billions of euros (e.g. destruction brought by a single flash flood event in 2002 in several southern French regions was estimated at 1.2 billion EUR) (Huet et al. 2003). Therefore, there is a necessity to develop a successful strategy to combat rainwater surpluses in cities ${ }^{1}$. Draining water with a sewage system has shortcomings: the flood risk increases as the water runs rapidly to the rivers and at that same time when the water is taken away from the natural environment, the phenomenon of the urban heat island intensifies as the level of ground and surface water drops down and urban greenery deteriorates (Niemczynowicz 1996).

In Stockholm Embrén (2015) found that planting beds rebuilt with structural soil surrounded by $4,600 \mathrm{~m}^{2}$ of roof and pavement surfaces, with rainfall of

\footnotetext{
${ }^{1}$ Following telephone consultations with National Water Management Authority (Państwowe Gospodarstwo Polskie Wody Polskie) officials, it was found that no estimates of losses caused by local flooding have been carried out in Warsaw.
}

$600 \mathrm{~mm}$ year, approximately retained 2.3 million 1 of water annually, that saved 2,300 GBP in annual costs for the treatment of rainwater. This reduced the load on the Baltic Sea and lakes following torrential rain (Embrén 2015). Warsaw needs a plan to counteract the effects of rain, such as the annex to the Plan for Adaptation of Copenhagen - CPH2025. The city authorities write about the need to increase Copenhagen's resilience to urban flash floods and flooding. The plan was created in 2012 and is projected to take at least 20 years to implement. Such plans are in line with such strategies as: Low Impact Development (LID) Water Sensitive Urban Design (WSUD) Sustainable Urban Drainage Systems (SUDS) (Hoyer et al. 2011).

Another aspect of structural soil is the possibility of its use for cleaning rainwater. Rainwater, after contact with roofs or roadways, can contain large amounts of substances such as suspensions, fats and oils, which can then be carried into lakes and rivers. Discharging them into water reservoirs is therefore particularly important in the context of water pollution and its impacts on existing flora and fauna. The smaller the size of the sewage system, the higher is the effect of these pollutants. The annual volume of rainwater sewage, which is then discharged by the municipal sewage system, is about $40 \%$ of the volume of municipal sewage in Poland. Rainwater contamination is also increased by the illegal connection of sanitation sewage to the rainwater sewage system. This affects the higher costs of water treatment and the dangerous state of surface water. Structural substrates have the potential of filtering rainwater, the use of vegetation also 
gives the opportunity to use the phenomenon of phytoremediation, therefore, the introduction of solutions such as in this article seems particularly justified (Fundacja Sędzimira 2016).

\section{Aspects of soil water retention}

Low Impact Development (LID) criteria, Sustainable Urban Drainage Systems (SUDs), Best Management Practices (BMPs), Water Sensitive Urban Design (WSUD) and more cover bioretention methods as effective management practices for urban storm water (Hsieh and Davis 2005, Fletcher et al. 2014). Analysing permeable pavements, one SUDs-related technique was found, that provides a large degree of attenuation in terms of reduction in peak flows, and extended duration of outflows compared with rain events (Abbott and Comino-Mateos 2003). However, not only surface material or landform can contribute to water retention, but the soil structure has such capacity itself. Soil structure has a profound influence on hydrological processes due to their distinct relationships to soil pore systems (Holden 1995, Nimmo 1997, Pachepsky and Rawls 2003). Pores provide for the passage and/ /or retention of gases and moisture within the soil profile. The soil's ability to retain water is strongly related to particle size; water molecules hold more tightly to the fine particles of a clay soil than to the coarser particles of a sandy soil, so clays generally retain more water. Conversely, sands provide easier passage or transmission of water through the profile. Clay type, organic content and soil structure also influence soil water retention (Charman and Murphy 1998). The issue of properties of soil (composition, texture, structure) that shape soil water relationships and water movement are a focus for agronomy scientists who try to combat climate changes in agriculture (Hamblin 1986, Suzuki et al. 2007, Easton and Bock 2016). It was observed that the amount of organic matter in a soil influences the water holding capacity. As the level of organic matter increases in a soil, the water holding capacity also increases (Hamblin 1986, Mamedov 2014). The maximum amount of water that a given soil can retain is called field capacity, whereas a soil so dry that plants cannot liberate the remaining moisture from the soil particles is said to be at wilting point. Available water is that which the plants can utilize from the soil within the range between field capacity and wilting point. Roughly speaking for agriculture, soil (top layer) is $25 \%$ water, $25 \%$ air, $45 \%$ mineral, $5 \%$ other; water varies widely from about $1 \%$ (gravel) to 90\% (peat soils) (Bednarek and Prusinkiewicz 1997, Bednarek and Skiba 2015 , Osman 2018) due to the various retention and drainage properties of a given soil (Leeper and Uren 1993, Embrén et al. 2009).

\section{Structural soil composition}

Structural soil was explored and defined in the 1990s by Cornell University Urban Horticulture Institute. Nowadays, many other companies have created their own brands of structural soil based on Cornell's work (Kalter 2008, America's Premier Paver 2010). Based on Cornell researchers' work, structural soil is a mixture of gap-graded gravels (made of crushed stone typically limestone or granite fraction 63-150 mm), clay loam, and a hydrogel stabilizing agent to keep 
the mixture from separating. It provides a root penetrable, high strength pavement system that shifts design away from individual tree pits (Bassuk et al. 1996, Embrén et al. 2009). Usually, a layer of stone is spread, then some authors recommend spreading a dry hydrogel evenly on top (Bassuk et al. 1996) or biochar (Embrén 2016) and screened moist soil with loam is placed on top. Soil is not typically stockpiled; it should be mixed and installed soon after delivery. If a stockpile is required, the soil needs to be protected from the elements so it does not become contaminated (Day and Dickinson 2008). The volume of crushed rock often has a total thickness of $600 \mathrm{~mm}$ or more. The crushed rock is laid in 250$-300 \mathrm{~mm}$ layers that are compressed by at least four passes with a vibroplate. The planting soil is applied in several layers so that the entire volume of crushed rock is saturated. There should be no surplus soil lying around after application. The crushed rock must be visible in a soil-filled boundary layer. The estimated amount of planting soil needed for $1 \mathrm{~m}^{3}$ crushed rock equals $0.25 \mathrm{~m}^{3}$ planting soil. In situations where the existing soil in the terrace has a clay content $>10 \mathrm{wt}-\%$, the clay content in the planting soil can be lower. However, the clay content in the planting soil should never be less than $4 \mathrm{wt}-\%$. The planting soil must meet the nutrient requirements as well. The structural soil is fertilized with slow-release fertilizer with eight months leaching time. The dose is $100 \mathrm{~g}$ per $1 \mathrm{~m}^{2}$, which in practice is equivalent to approx. one handful per $1 \mathrm{~m}^{2}$. Fertilization is carried out during the construction of the structural soil and the fertilizer is applied in layers with the planting soil.
To level off the structural skeleton, a $200 \mathrm{~mm}$ aerated bearing layer of $32-63 \mathrm{~mm}$ crushed rocks laid on top. The material is compressed with a $400 \mathrm{~kg}$ soil vibrator. Geotextile is laid on top of the aerated bearing layer, followed by a suitable surface layer for the specific project (Embrén et al. 2009). The surface layer could be created as permeable or impermeable. A permeable surface allows infiltration on its own, pavements designed as impermeable must foresee the possibility of oxygen and water entering the system. For that reason, inlets are installed, mostly in the pavement, to the ventilated bearing layer and the structural soil (Fig. 1).

\section{MATERIAL AND METODS}

\section{Aim of the research}

Our key research question is to determine whether using a structural soil under pedestrian and courtyard surfaces in urban areas can substantially increase their water retention capacity.

The aim of the investigation is to demonstrate the effectiveness of the previously rarely tested properties of using structural soil to increase water retention capacity. We hypothesized that the use of a structural substrate may have a wider application than the improvement of urban trees' habitat conditions.

\section{Research material}

The study area is in the Praga Północ quarter in Warsaw. The selected fragment is limited by Targowa street, Jagiellońska street, Solidarności avenue and Zamoyskiego street (Fig. 2). The area covers about 17 ha. 


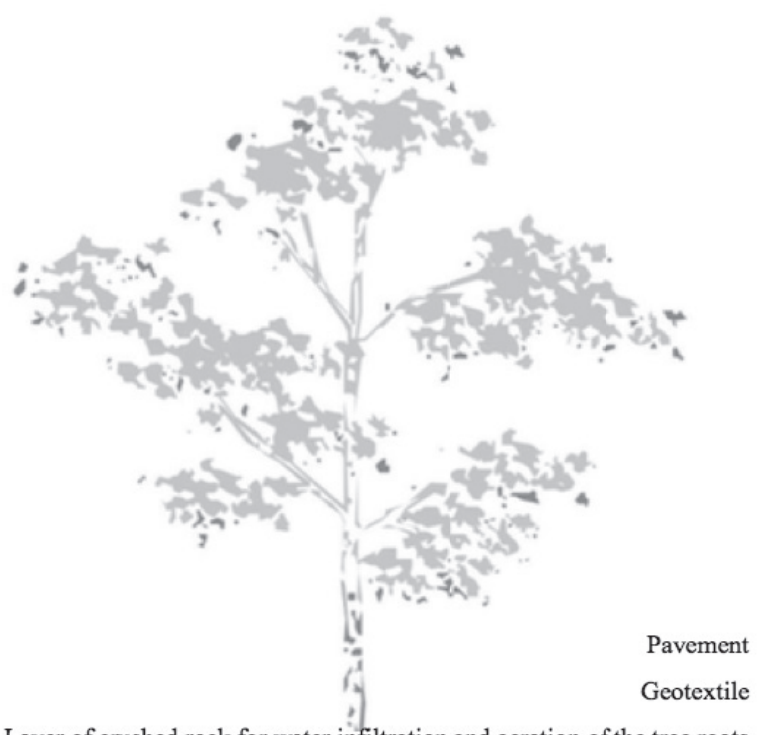

Layer of crushed rock for water infiltration and aeration of the tree roots

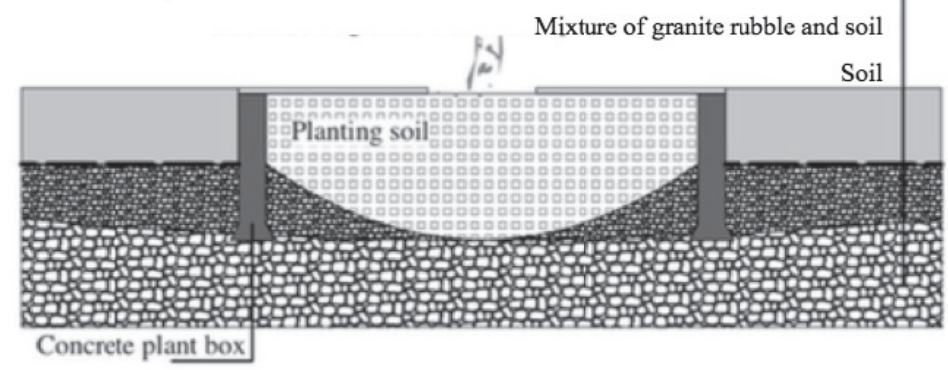

FIGURE 1. Cut-through plan of the installation of structural soil for the tree growth Source: Own elaboration on the basis of Embrén et al. (2009).

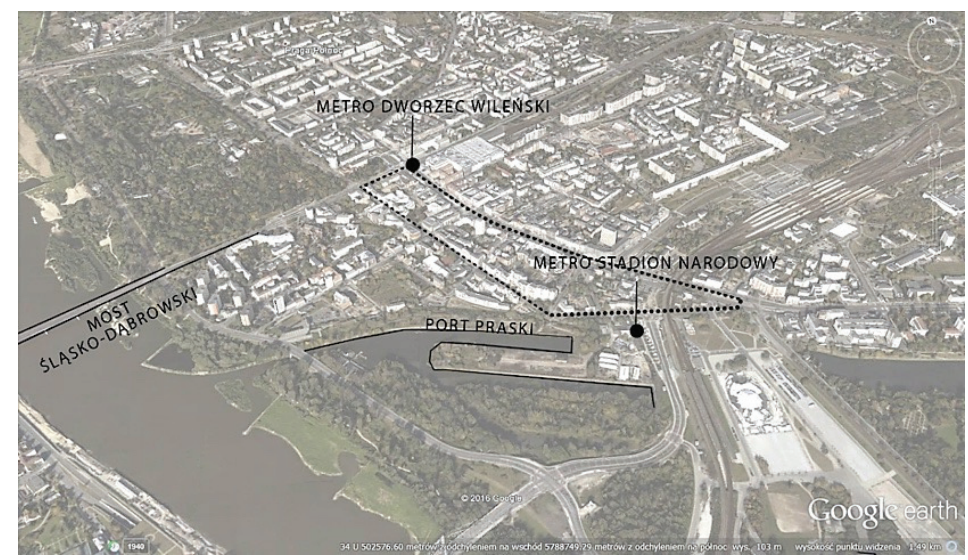

FIGURE 2. Study area location

Source: Warmińska (2016). 


\section{Method of conducting qualitative research}

The area of study was analysed using GIS data, satellite images and an on-site verification studies. Terrain elevation analysis showed an incline of the area towards the Vistula. The northern part of the area about $90 \mathrm{~m}$ above sea level, while in the south $-82 \mathrm{~m}$ above sea level (Fig. 3). The numerical model of the area available on the geoportal does not show clear denivelations and depressions, which can significantly shape surface water flow.

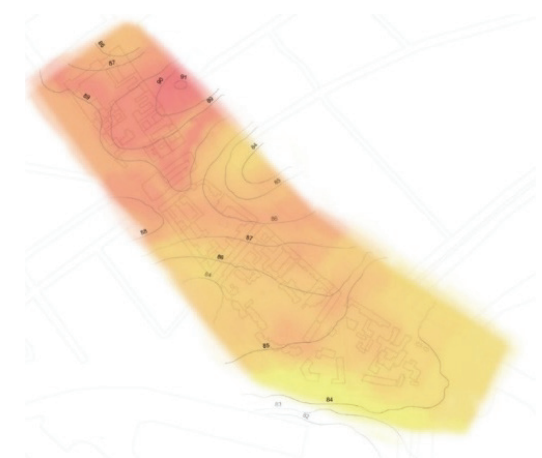

FIGURE 3. Terrain elevation model Source: Own elaboration.

Generally, the area is relatively flat. The biologically vital area (rbva) occupies only $15 \%$ of the entire study area. As much as $63 \%$ of the area is covered by buildings and impermeable surfaces, which means that rainwater from this area goes straight to the municipal sewage system. In addition, $21 \%$ of the surface is semi-permeable surfaces, such as flagstones or paving stones, which only to a small extent allow infiltration of water into the ground. At the analysed site, there are so-called concreted wells, that is, the courtyards of old tenements, to which little sun reaches. They are often covered only with concrete slabs or asphalt (Figs. 4, 5) with no connection to the city drainage system. Only narrow strips of vegetation with firm consistency of soil could be described as biologically vital area that enables water infiltration. However, the current state of those strips does not imply any substantial water infiltration capacity.

The proximity of the metro station and important streets with high volume traffic, as well the location of the tram line along Targowa street, numerous bus
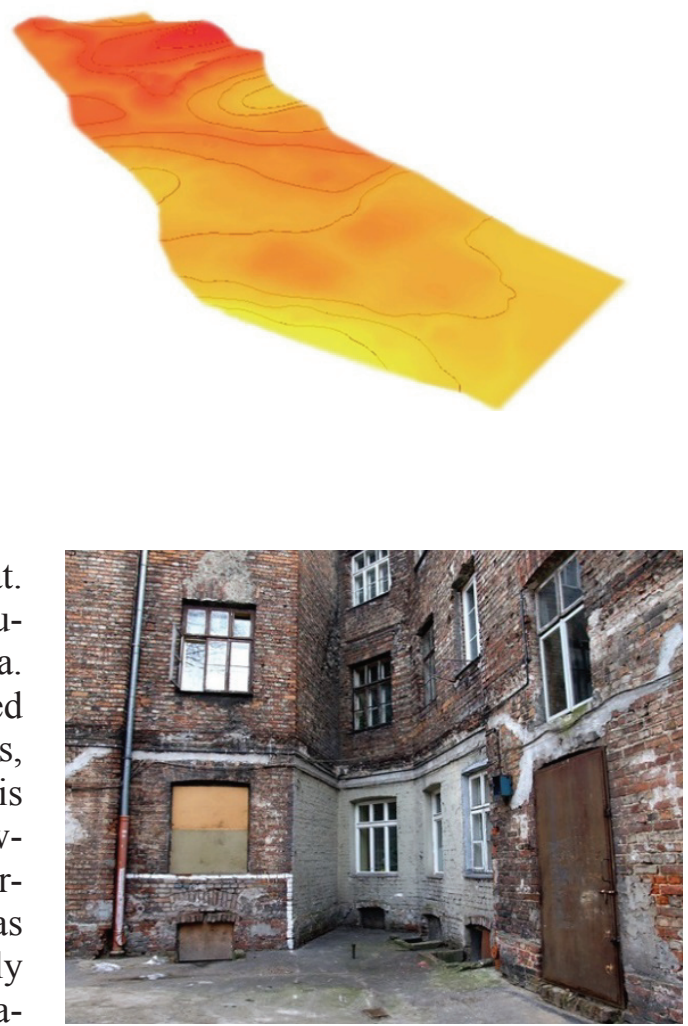

FIGURE 4. One of the courtyards on Okrzei street

Source: warszawa78.blox.pl [access 01.03.2016]. 


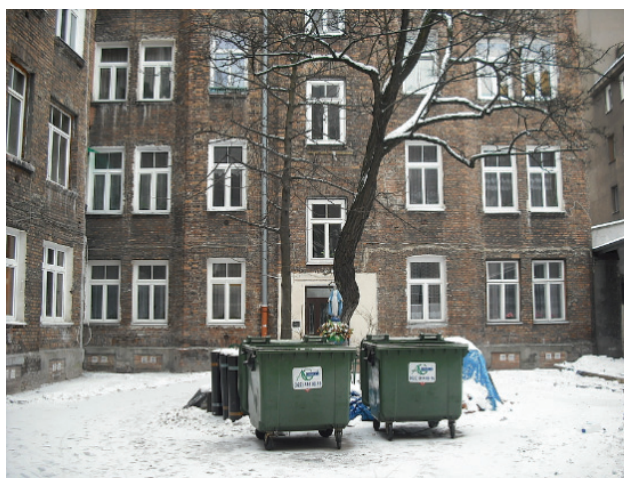

FIGURE 5. One of the courtyards on Okrzei street

Source: warszawa78.blox.pl [access 01.03.2016].

stops, railway tracks, located on a reinforced concrete viaduct, are elements of strong anthropopressure. The on-site verification and analysis of satellite images uncovered a substantial number of parking spaces in this area. Parking spaces occur along each of the streets, including internal ones. At the same time, apart from them, there are many "wild" parking lots in courtyards. There are often large areas of completely unused land, which are used only for parking covered with impermeable surfaces (Fig. 6). There are very few trees along Targowa street and Jagiellońska street

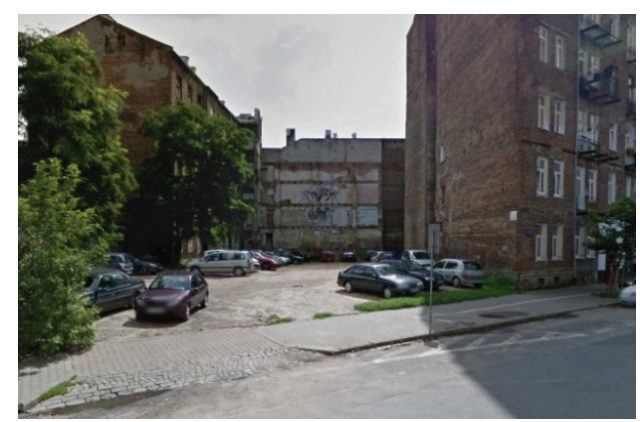

FIGURE 6. Parking on Sprzeczna street

Source: Google maps - street view mode [access 05.03.2016].
(Fig. 7). The greater density of large trees can be seen in the square around the gas station in the southern part of the area and around the playground in the northern part. Analysing the official land use type, these car parks were found to occupy approximately $10 \%$ of the whole study area (Warmińska 2016). It is not clear how the courtyard surfaces between tenements, especially basements and foundations walls, may change the direction of groundwater runoff. This factor may delay water outflow in the study area, where there is a high groundwater table - located at a depth of 1.5-2 m below ground level (Mapa hydrogeologiczna Polski).

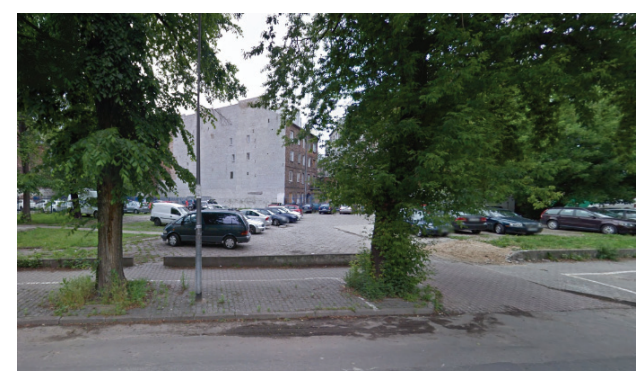

FIGURE 7. Parking on Jagiellońska street

Source: Google maps - street view mode [access 05.03.2016].

The method of conducting quantitative research includes: conversion of the surface area based on Open Street Map data, calculation of the volume of the potential structural soil under all paved areas (excluding asphalt pavements), basing on soil porosity ratio, a certain volume can be filled with rainwater. The land use types (surfaces) were calculated using layers from Internet portal OpenStreetMaps minus buildings with digitized layers of orthophotomaps (surfaces currently paved under pavements/car 
parks, interior courtyards and unpaved surfaces). The properties of the structural soil were based on parameters specified in the technical specification (Suchocka 2016).

\section{RESULTS}

Results show that performance of structural soil considering its porosity in terms of possible water retention could influence rainwater retention capacity. The maximum heavy rain in Warsaw (the western part of the city has more rainfall than the eastern part) took place in 2013 and lasted about $1.5 \mathrm{~h}$. At the rainwater station in Bielany, it was reported that $38.9 \mathrm{~mm}$ of rain fell (9 June) (IMGW-PIB 2013). The costs were estimated assuming such rainfall over the analysed site in Praga Północ, a total of around $6,502 \mathrm{~m}^{3}$ of rain. At the same time, supposing we insert a structural substrate under the pavement, taking into consideration only a thickness of $10 \mathrm{~cm}$, we gain over $7,395 \mathrm{~m}^{3}$ of volume of base layer to use (which is only a small part of the whole base layer) - the table. Considering a porosity rate of $30 \%-2,218.5$ $\mathrm{m}^{3}$ of water can be retained there, which is more than one third of the maximum heavy rain that fell in 2013.

Comparing the costs of installing softscape solution - structural soil under the pavement in a city and a popular hardscape solution distributed by Wavin - box structure infiltration units
- AquaCell, it was estimated that the costs of the first option would be around 300 PLN net for $1 \mathrm{~m}^{2}$, while the costs of implementation of AquaCell including the execution of excavation under the box, wrapping it with a layer of geotextile, making embankments, as well as labour and overheads assuming box dimensions of $1.2 \times 0.6 \times 0.6 \mathrm{~m}$, and its area of the horizontal projection -0.72 $\mathrm{m}^{2}$ the costs would be around 1,135 PLN net. Similar costs to the box structure were estimated for the attenuation tank, however one should additionally consider larger excavation works if deciding on this solution. The attenuation tanks are prefabricated structures with specific sizes, not always capable of being adapted to certain conditions (underground city infrastructure might be problematic in this case).

All three solutions have different effects depending on the season. When there is a lot of rain and the level of groundwater rises, the retention capacity decreases. All three solutions cannot be placed in the direct vicinity of the underground infrastructure (cables, sewage). However, structural soil can be used in the direct vicinity of trees and other green areas which gives more options for usage and more extensive possible areas to cover. Considering possibility of placing box structures and attenuation tanks, one should bear in mind the legal act defining all the distances that should be kept - the ordinance of the Minister of

TABLE. Water retention capacity of total volume of $10 \mathrm{~cm}$ thick layer of structural soil (p)

\begin{tabular}{|l|c|c|c|}
\hline Study area - land use & Area $\left(\mathrm{m}^{2}\right)$ & Area $(\%)$ & $\mathrm{p}\left(\mathrm{m}^{3}\right)$ \\
\hline Unpaved area & 32593.22 & 19.5 & 3259.32 \\
\hline Sidewalks and courtyards mostly paved & 73953.07 & 44.2 & 7395.31 \\
\hline
\end{tabular}


Infrastructure of 12 April 2002 on technical conditions that should be met by buildings and their location (with later changes and amendments):

- the minimum distance of boxes installed from a plot's boundary is $2 \mathrm{~m}$;

- the minimum distance of drainage from the nearest well is $30 \mathrm{~m}$;

- the minimum distance of boxes from a residential building is $3 \mathrm{~m}$;

- the minimum distance of leaching boxes from trees and shrubs is $3 \mathrm{~m}$.

Such requirements do not refer to the use of structural soil.

Comparing rainwater capacity, considering structural soil's $30 \%$ porosity, the accumulation capacity is about 3001 per $1 \mathrm{~m}^{3}$. In turn, drainage boxes have an accumulative capacity of up to 9501 per $1 \mathrm{~m}^{3}$ of box. It seems to be three times more capacity than structural soil, which impacts the reduction of the drainage area. Analysing long-term maintenance, structural soil has the best performance during the first years of implementation. Over time, fallen leaves, as well as garbage collected by the gutter system, contribute to the clogging of a gravel system. Cleansing such a system is very costly and laborious, contrary to box structures, which, according to the producer's warranty, have no such problems, because they are wrapped in geotextile which prevents clogging.

Structural soil, as a tree-friendly solution, could be considered a solution that brings additional benefits for a city by saving money, thanks to new plantings or keeping old trees in urban areas. For every 1 USD spent on trees, a return of 2.70 USD in benefits is received, according to the US Forest Service. A similar study performed in the UK by Natural
England calculated that every $1 \mathrm{GBP}$ spent on tree planting yielded 7 GBP savings, or a potential 2.1 billion GBP if taken nationally analysing value of carbon dioxide sequestered by megacity tree cover, reduced ozone in the air, reduced costs for public health (Livesley et al. 2016), rainwater management (Grey et al. 2018), energy savings (Pandit and Laband 2010), prevention of soil erosion urban heat islands (McPherson et al. 1997, Norton et al. 2015), and other services. Therefore, structural soil seems to be a more flexible solution for the urban conditions expected in Praga Północ in Warsaw and seems to bring more benefits than other options. Structural soil can be used along streets next to dense urban fabric including buildings, as well as in the direct vicinity of trees.

\section{DISCUSSION}

Using structural soil in city areas to reduce flash floods and reduce urban droughts is an attempt to combat climate change and increase city resilience. Warsaw suffers from a lack of ground permeability. The ratio of impermeable surfaces sealed to the total area of a given basin in the city centre is 0.9 , while on the city outskirts 0.4-0.7 (Wagner and Krauze 2014). The presence of rubble and the remains of bricks after the WWII and other debris underground, may positively influence infiltration in Praga Północ located on mostly clay, but recent flash floods observed there prove that it is not sufficient (Mazur 2018).

The aspect of the origin of the organic part of the structural medium as an additional ecological aspect of the study 
is worth further research. Considering the possibility of increasing water retention, it is important that this organic matter has an ability to absorb water and release it to plants effectively (Funderburg 2001). Therefore, it has a low field capacity. Many meadow and peatland owners would like to find a method for cheap management of gathering the top layer of a degraded peat bog. There have been attempts to adopt compost soil in a structural base (Austrian Federal Ministry of Agriculture, Forestry, Environment and Water Management, Communities 2003). Such compost soil, which was to be used in the city, not in vegetable garden areas could be cheaply obtained thanks to the composting Wastewater Treatment Plant Czajka. The city of Warsaw ran the production of compost there for some time, but the presence of heavy metals in this compost meant that there was too much risk for using it in horticulture (Cyganecka and Majszczyk 2011). Heavy metal contamination of soil may pose risks and hazards to humans and the ecosystem through: direct ingestion or contact with contaminated soil, the food chain (soil-plant-human or soil-plant-animal-human), drinking of contaminated ground water, reduction in food quality (safety and marketability) via phytotoxicity, reduction in land usability for agricultural production causing food insecurity, and land tenure problems (McLaughlin et al. 2000, Ling et al. 2007). Consequently, production was limited. However, such applications - increasing retention and adding soil to urban greenery could be a valuable option.

The management of rainwater in cities should start at the level of individual projects, emerging investments. The reason for difficulties in implementing alternative solutions in the field of small retention is Polish legislation, which makes it difficult to introduce such solutions to projects. The interdisciplinary aspect of the planning of such solutions is also important. Experts from areas such as landscape architecture, architecture, construction, utilities, hydrology, geology, and ecology should cooperate to create the most sustainable system that will respond to climate change, improving city resilience and translating into the comfort of the life of residents (City of Copenhagen 2012).

\section{CONCLUSIONS}

Structural soil would improve the rainwater retention in the analysed part of Praga Północ in Warsaw. After calculating the volume of potential structural soil in all hard areas (except for asphalt pavements) and considering porosity, it seems that we obtain at least $2,218.5 \mathrm{~m}^{3}$ in volume (considering top $10 \mathrm{~cm}$ of this layer), which can be filled with rainwater. Structural soil used in the base layer under pavements and courtyards that cover ca. $44 \%$ of the study area may hold ca. 34\% of rainwater (based on heavy rain rate in 2013 in Bielany). The hypothesis, that it can have a significant impact on improving water retention has been confirmed. Only a $10 \mathrm{~cm}$ layer of the base was analysed for its water retention capacity, however the layer of structural soil is usually ca. $50 \mathrm{~cm}$ or more (depending on the silty and clay particle content in the ground). The possible effectiveness of this bio-retention method 
is even greater. The properties of structural soil should be made to fit its main function. If the aim is to infiltrate water underground and reduce the risk of flash floods in Praga Północ the amount of soil should not be high, however if the aim is to hold appropriate site (and water) conditions for urban trees, the amount of soil should be significant, as this factor influences water-holding capacity and at the same time provides the right conditions for the development of tree roots.

\section{REFERENCES}

ABBOTT C.L., COMINO-MATEOS L. 2003: In-Situ hydraulic performance of a Permeable Pavement Sustainable Urban Drainage System. Water Environ. J. 17 (3): 187-190.

America's Premier Paver n.d.: Structural Soil. Retrieved from: http://www.americaspremierpaver.com/alliedproducts/ structural_soil.htm [access 12.11.2018].

Austrian Federal Ministry of Agriculture, Forestry, Environment and Water Management, European Communities 2003: Applying Compost Benefits and Needs, 2001: Seminar Proceedings, 22-23.11.2011 Brussels. Retrieved from: http://ec.europa.eu/environment/archives/waste/pdf_comments/040119_ proceedings.pdf [12.11.2018].

BASSUK N., GRABOSKY J., TROWBRIDGE P., URBAN J. 1996: Structural Soil: A innovative medium under pavement that improves street tree vigor. American Society of Landscape Architects Annual Meeting. Retrieved from: http://www.hort.cornell.edu/ uhi/outreach/csc/article.html [access 12.11.2018].

BEATLEY T. 2008: Planning for Sustainability in European Cities: A Review of practice in Leading Cities. The Sustainable
Urban Development Reader. Routledge, London.

BEDNAREK R., PRUSINKIEWICZ Z. 1997: Geografia gleb [Soil geography]. 4th edn. Wydawnictwo Naukowe PWN, Warszawa.

BEDNAREK R., SKIBA S. 2015: Geografia gleb świata [Soil geography of the world]. In: A. Mocek (Ed.), Gleboznawstwo. 1st edn. Wydawnictwo Naukowe PWN, Warszawa: 405-406.

CHARMAN P.E.V., MURPHY B.W. 1998: Soils: Their Properties and Management. 5th edn. Oxford University Press, Melbourne.

City of Copenhagen 2012: Cloudburst Management Plan. Retrieved from: https:// en.klimatilpasning.dk/media/665626/ $\mathrm{cph}$ __cloudburst_management_plan.pdf [access 12.11.2018].

CYGANECKA A., MAJSZCZYK I. 2011: Sewage Sludge Treatment in Warsaw - Current Situation in Poland. In: K.J. Thomé-Kozmiensky, L. Pelloni (Eds.), Waste Management. Vol. 2. Waste Management, Recycling, Composting, Fermentation, Mechanical-Biological Treatment, Energy Recovery from Waste, Sewage Sludge Treatment. TK Verlag Karl Tomé-Kozmiensky, Neuruppin: 700-712.

DAY S.D., DICKINSON S.B. (Eds.) 2008: Managing Stormwater for Urban Sustainability using Trees and Structural Soils. Virginia Polytechnic Institute and State University, Blacksburg, VA.

EASTON Z., BOCK E. 2016: Soil and Soil Water Relationships. Virginia Cooperative Extension, Virginia Tech, Virginia State University, St. Petersburg, VA.

EMBRÉN B. 2015: Plant Beds in Stockholm City Trees and Stormwater Management. The Stockholm Solution Street Department, Stockholm.

EMBRÉN B. 2016: Planting Urban Trees with Biochar. tBJ: 44-47. Retrieved from: www.biochar-journal.org/en/ct/77 [access 12.11.2018]. 
EMBRÉN B., ALVEM B-M., STÅL Ö., ORVESTEN A. 2009: Planting Beds in the City of Stockholm. A Handbook. Stockholm.

FLETCHER T., SHUSTER W., HUNT W., ASHLEY R., BUTLER D., ARTHUR S., TROWSDALE S., BARRAUD S., SEMADENI-DAVIES A., BERTRANDKRAJEWSKI J-L., MIKKELSEN P.S., RIVARD G., UHL M., DAGENAIS D., VIKLANDER M. 2015: SUDS, LID, BMPs, WSUD and more - The evolution and application of terminology surrounding urban drainage. Urban Water J. 12 (7): 525-542.

Fundacja Sędzimira 2014: Duże plusy małej retencji [The big advantages of small retention]. Retrieved from: https://uslugiekosystemow.pl/2014/01/23/duze-plusymalej-retencji [access 12.11.2018].

FUNDERNURG E. 2001: What Does Organic Matter Do in Soil? Noble News and Views, August. Retrieved from: https://www.noble.org/news/publications/ag-news-and-views/2001/august/ what-does-organic-matter-do-in-soil [access 12.11.2018].

GRABOSKY J., BASSUK N. 1996: Testing of structural urban tree soil materials for use under pavement to increase street tree rooting volumes. J. Arboricult. 22 (6): 255-263.

GREY V., LIVESLEY S.J., FLETCHER T.D., SZOTA C. 2018: Establishing street trees in stormwater control measures can double tree growth when extended waterlogging is avoided. Landscape Urban Plan. 178: 122-129.

HAMBLIN A. 1986: The Influences of Soil Structure on Water Movement Crop Root Growth, and Water Uptake. Advan. Agron. 38: 95-158.

HOJNY A. 2018: Warszawa płynie. Zalane ulice, podtopione domy [Warsaw is flowing. Flooded streets, flooded houses]. Super Express. Retrieved from: https:// www.se.pl/warszawa/warszawa-plyniezalane-ulice-podtopione-domy-aa-AtX3wrj9-7XVP.html [access 12.11.2018].
HOLDEN N.M. 1995: Temporal variation in ped shape in an old pasture soil. Catena 24: 1-11.

HOYER J., DICKHAUT W., KRONAWITTER L., WEBER B. 2011: Water Sensitive Urban Design - Principles and Inspiration for Sustainable Stormwater Management in the City of the Future. HafenCity Universität, Hamburg. Retrieved from: http://www.switchurbanwater.eu/outputs/pdfs/W5-1_GEN_MAN_ D5.1.5_Manual_on_WSUD.pdf ${ }^{-}$[access 12.11.2018].

HSIEH C-H., DAVIS A.P. 2005: Multiple-event study of bioretention for treatment of urban storm water runoff. Water Sci. Technol. 51 (3-4): 177-181.

HUET P., MARTIN X., PRIME J-L., FOIN P., LAURAIN C., CANNARD P. 2003: Retour d'expérience des crues de septembre 2002 dans les départements du Gard, de l'Hérault, du Vaucluse, des Bouches-des-Rhône, de l'Ardèche et de la Drôme. Rapport. Inspection Generale De L'environnement, Paris.

Instytut Meteorologii i Gospodarki Wodnej - PIB 2013: Warunki termiczno-opadowe na obszarze Warszawy w 2012 r. oraz w pierwszym i drugim kwartale $2013 \mathrm{r}$. [Thermal and precipitation conditions in Warsaw in 2012 and in the first and second quarters of 2013]. Warszawa.

KALTER B. 2008: CU-Soil. Amereq, Inc. Retrieved from: http://amereq.com/pages/2/index.htm [access 12.11.2018].

LEEPER G.W., UREN N.C. 1993: Soil Science: An Introduction. 5th edn. University Press, Melbourne.

LING W., SHEN Q., GAO Y., GU X., YANG Z. 2007: Use of bentonite to control the release of copper from contaminated soils. Aust. J. Soil Res. 45 (8): 618-623.

LIVESLEY S.J., McPHERSON E.G., CALFAPIETRA C. 2016: The urban forest and ecosystem services: Impacts on urban water, heat, and pollution cycles at the tree, street, and city scale. J. Environ. Qual. 45: 119-124. 
McHARG I. 1967: An Ecological Method for Landscape Architecture. Landscape Architecture 57: 105-107.

McHARG I. 1969: Design with Nature. 18th edn. Harvard, New York.

McLAUGHLIN M.J., ZARCINAS B.A., STEVENS D.P., COOK N. 2000: Soil testing for heavy metals. Comm. Soil Sci. Plant Anal. 31 (11-14): 1661-1700.

McPHERSON E.G., NOWAK D., HEISLER G., GRIMMOND S., SOUCH C., GRANT R. 1997: Quantifying urban forest structure, function, and value: The Chicago Urban Forest Climate Project. Urban Ecosystems 1 (1): 49-61.

MAMEDOV A. 2014: Soil water retention and structure stability as affected by water quality, Euroasian Journal of Soil Science. Retrieved from: http://dergipark. gov.tr/download/article-file/62852 [access 12.11.2018].

Mapa hydrogeologiczna Polski w skali 1:50000 [Hydrogeological map of Poland in 1:50000 scale]. Państwowy Instytut Geologiczny. Retrieved from: https:// www.pgi.gov.pl/psh/dane-hydrogeologiczne-psh/947-bazy-danych-hydrogeologiczne/8888-dane-hydrogeologicznemhp.html [access 12.11.2018].

MAZUR F. 2014: Ulewa nad Warszawa. Zalane ulice, podtopiony Centralny [Heavy rain over Warsaw. Flooded streets, flooded Central]. Wyborcza.pl. Retrieved from: http://warszawa.wyborcza.pl/warszawa/ $1,54420,16462179$, Ulewa nad Warszawa_Zalane_ulice_podtopiony_Centralny.html [access 12.11.2018].

NIEMCZYNOWICZ J. 1996: Megacities from a Water Perspective. Water International 21 (4): 198-205.

NIMMO J.R. 1997: Modeling structural influences on soil water retention. SSSAJ 61 (3): 712-719.

NORTON B.A., COUTTS A.M., LIVESLEY S.J., HARRIS R.J., HUNTER A.M., WILLIAMS N.S.G. 2015: Planning for cooler cities: A framework to prioritise green infrastructure to mitigate high tem- peratures in urban landscapes. Landscape Urban Plan. 134: 127-138.

OSMAN K.T. 2018: Peat Soils. Management of Soil Problems. Springer, Cham.

PACHEPSKY Y.A., RAWLS W.J. 2003: Soil structure and pedotransfer functions. Eur. J. Soil Sci. 54: 443-451.

PANDIT R., LABAND D.N. 2010: Energy savings from tree shade. Ecol. Econ. 69: 1324-1329.

Rozporządzenie Ministra Infrastruktury $\mathrm{z}$ dnia 12 kwietnia 2002 r. w sprawie warunków technicznych, jakim powinny odpowiadać budynki i ich usytuowanie. Dz.U. $2002 \mathrm{nr} 75$, poz. 690 [Regulation of the Minister of Infrastructure of 12 April 2002 on the technical conditions to be met by buildings and their location. Journal of Laws 2002 No 75, item 690].

SUCHOCKA M. 2016: Podłoże strukturalne [Structural background]. Specyfikacja techniczna dla Zarządu Inwestycji Miejskich w Łodzi, Łódź.

SUZUKI S., NOBLE A., RUAYSOONGNERN S., CHINABUT N. 2007: Improvement in Water-Holding Capacity and Structural Stability of a Sandy Soil in Northeast Thailand, Arid Land Research and Management 21 (1): 37-49.

US Forest Service n.d.: Trees. Retrieved from: https://www.fs.fed.us/learn/trees [access 28.05.2019].

WAGNER I., KRAUZE K. 2014: Jak bezpiecznie zatrzymać wode opadowa w mieście? Narzędzia techniczne [How to safely keep rainwater in the city? Technical tools]. In: T. Bergier, J. Kronenberg, I. Wagner (Eds.), Woda w mieście. Seria Zrównoważony Rozwój - Zastosowania 5. Fundacja Sędzimira, Warszawa: 75-93.

WARMIŃSKA M. 2016: Zwiększenie stopnia rezyliencji miasta poprzez zrównoważone gospodarowanie wodą opadową na przykładzie fragmentu dzielnicy Praga Północ [Increasing the degree of city resilience through sustainable rainwater management on the example of a frag- 
ment of the Praga Północ district]. MSc thesis. SGGW, Warszawa [typescript].

WELLE T., BIRKMANN J. 2015: The World Risk Index - An Approach to Assess Risk and Vulnerability on a Global Scale. J. Extreme Events 2. https://www. doi.org/10.1142/S2345737615500025

WOJNOWSKA-HECIAK M., JANUS A. 2016: Landscape solutions for small retention. Structure and Environment 27: $40-46$.

Streszczenie: Zastosowanie podłoża strukturalnego jako metody zwiększenia powodziowej rezyliencji na Pradze Pólnoc w Warszawie. Celem dociekań jest wykazanie skuteczności nieanalizowanych dotąd właściwości zastosowania podłoża strukturalnego do zwiększenia pojemności retencyjnej. Sposób przeprowadzenia badań obejmuje: przeliczenie powierzchni poszczególnych powierzchni występujących na terenie opracowania, przeliczenie objętości potencjalnego podłoża strukturalnego pod wszystkimi obszarami utwardzonymi (poza nawierzchniami asfaltowymi jezdni) przy uwzględnieniu porowatości tego podłoża, co pozwala na uzyskanie wartości objętości, w którą mogą wypełnić wody deszczowe. Przyjmując parametry maksymalnego deszczu nawalnego notowanego dla zachodniej części Warszawy (stacja opadowa na Bielanach opad nawalny z 2013 roku $-38,9 \mathrm{~mm}$, czas trwania 1,5 h), obliczono, że na analizowany obszar spadłoby łącznie około $6502 \mathrm{~m}^{3}$ deszczu. Przy założeniu, że pod chodnikami i dziedzińcami znajduje się podłoże strukturalne o miąższości $10 \mathrm{~cm}$ i porowatości wynoszącej średnio 30\%, uzyskano by ponad $2218,5 \mathrm{~m}^{3}$. Wnioski sprowadzają się więc do stwierdzenia, że podłoże strukturalne zastosowane pod nawierzchniami pieszymi i dziedzińcami budynków znacząco się poprawiło. Retencja wód opadowych na analizowanym fragmencie dzielnicy Praga Północ w Warszawie może znacząco zredukować lokalne podtopienia.

Stowa kluczowe: podłoże strukturalne, rezyliencja powodziowa, retencja wodna

MS received: 19.12 .2018

MS accepted: 21.10.2019

\section{Authors' address:}

Magdalena Wojnowska-Heciak (https://orcid.org/0000-0002-7043-9559)

Wydział Budownictwa i Architektury

Politechnika Świętokrzyska

al. Tysiąclecia Państwa Polskiego 7, 25-314 Kielce

Poland

e-mail: mwojnowska@tu.kielce

Marzena Suchocka

(https://orcid.org/0000-0002-0759-5348)

Marta Warmińska

Katedra Architektury Krajobrazu

Wydział Budownictwa i Inżynierii Środowiska

Szkoła Główna Gospodarstwa Wiejskiego

w Warszawie

ul. Nowoursynowska 166, 0-787 Warszawa

Poland 